\title{
A NEW SPECIES OF PLEUROTHALLIS (ORCHIDACEAE) FROM COLOMBIA
}

\author{
Max RyKaCZEwSKI ${ }^{1}$ \& Marta KolanowsKa
}

\begin{abstract}
A new species of Pleurothallis subsect. Antenniferae Luer is described and illustrated based on Colombian material. The taxonomic affinity of the novelty is briefly discussed. An updated key for identification of Colombian representatives of $P$. subsect. Antenniferae is presented.
\end{abstract}

Key words: Anteniferae, Colombia, distribution, new species, Pleurothallidinae, taxonomy

Max Rykaczewski \& Marta Kolanowska, Department of Plant Taxonomy and Nature Conservation, University of Gdańsk, Wita Stwosza 59, 80-308 Gdańsk, Poland; e-mail: max.rykaczewski@gmail.com

\section{INTRODUCTION}

The genus Pleurothallis Luer is one of the largest among the Neotropical Orchidaceae. The great variation of both morphological and floral characters observed within this taxon has led to much discussion of its infrageneric classification and delimitation of smaller genera (e.g., Borba et al. 2000; Pridgeon \& Chase 2001; Pridgeon et al. 2001; Luer 2002). The first comprehensive study of the taxonomy of Pleurothallis (Luer 1986) recognized 29 subgenera within three 'affinities', and the nominal subgenus was divided initially into four sections. In the modified classification, Luer $(1998,1999)$ reduced the number of sections within Pleurothallis subg. Pleurothallis to three. Two of them, Abortivae Luer and Truncatae Luer, were described as unispecific taxa, and the nominal section was divided into seven subsections distinguishable by leaf form (petiolate or sessile) inflorescence structure and floral characters (lip shape).

Pleurothallis subsect. Antenniferae Luer, typified by P. antennifera Lindl. (Luer 1999), included 38 species characterized by the welldeveloped ramicauls which are commonly longer than the leaf. The inflorescence of members of this subsection usually is racemose, and arises from the leaf base. The flowers are resupinate. The dorsal sepal is essentially free, while the lateral sepals are connate, forming a concave synsepal. The petals are entire, narrowly oblong to linear. The lip usually is variously recurved near the middle $\left(90^{\circ}\right.$ or $\left.180^{\circ}\right)$. The gynostemium is semiterete and short, and the column foot is abbreviated. Pleurothallis subsect. Antenniferae is distinguished from the most similar $P$. subsect. Longiracemosae by the presence of distinct or prolonged lip lateral lobes and commonly linear petals (Luer 1998).

Representatives of $P$. subsect. Antenniferae are restricted in their distribution to South America, reported from Colombia to Bolivia, including Trinidad and the Guyana Shield. Species diversity is highest in the northern Andes: Ecuador (28 species) and Colombia (16 species). Populations usually grow in humid forests (Luer 1999).

During studies of Colombian orchids we found a distinctive representative of the subsection. Because it does not match the morphological characteristics of any known taxon it is described here as a new species.

\footnotetext{
1 Corresponding author
} 


\section{TAXONOMIC TREATMENT}

Pleurothallis narinoensis Rykaczewski \& Kolan., sp. nov.

Fig. 1

Species similar to $P$. antennifera Lindl., $P$. ramificans Luer and $P$. taurus Luer, distinguished by the proliferating ramicauls, linear-elliptic leaves, linear-lanceolate, acute lip lateral lobes, and semicircular middle lobe with irregular margins, covered at the base by a transverse foveolate ridge and with a linear-oblong, acute apicule.

Holotype: COlOMBIA, Dept. Nariño, Páramo de Quilinsayaco, between La Cocha and Santiago, Alt. 2700-3000 m, 1 August 1961, Garay L.A. 424, McClennen C.E. \& Kapuler A. (MO 6484977).

Large, repent plants, $c a 40 \mathrm{~cm}$ tall. Roots slender. Ramicauls 7-11 cm long, erect, proliferating, enclosed by one sheath at base and one in middle of
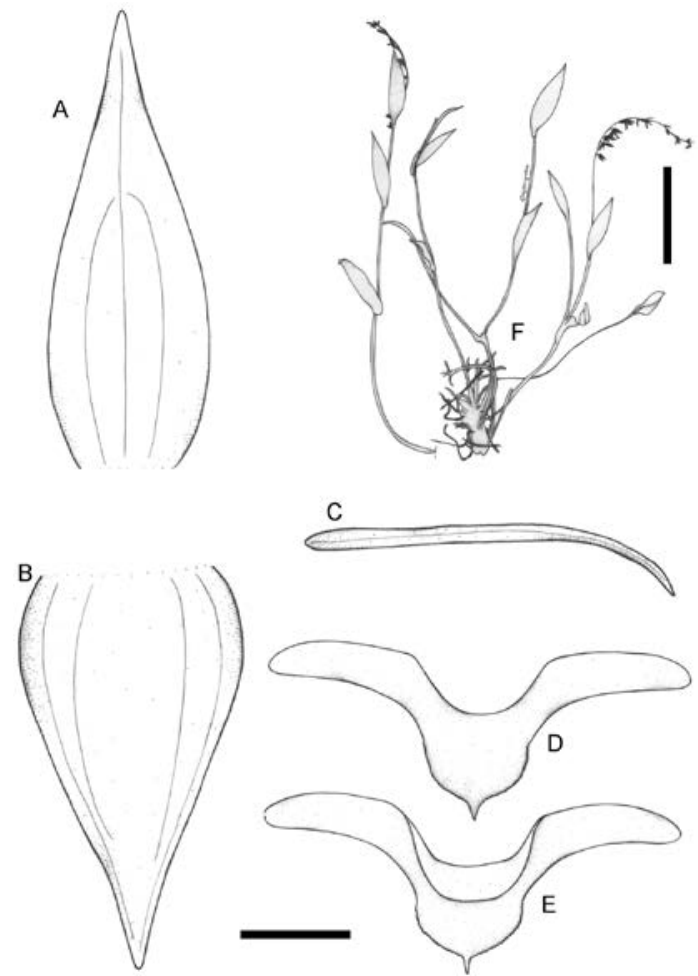

Fig. 1. Pleurothallis narinoensis Rykaczewski \& Kolan., sp. nov. A - dorsal sepal, B - synsepal, C - petal, D - lip: dorsal view, $\mathrm{E}$ - ventral view, $\mathrm{F}$ - whole plant. Scale bar A-E $=2 \mathrm{~mm}$, $\mathrm{F}=10 \mathrm{~cm}$. Drawn by N. Olędrzyńska.

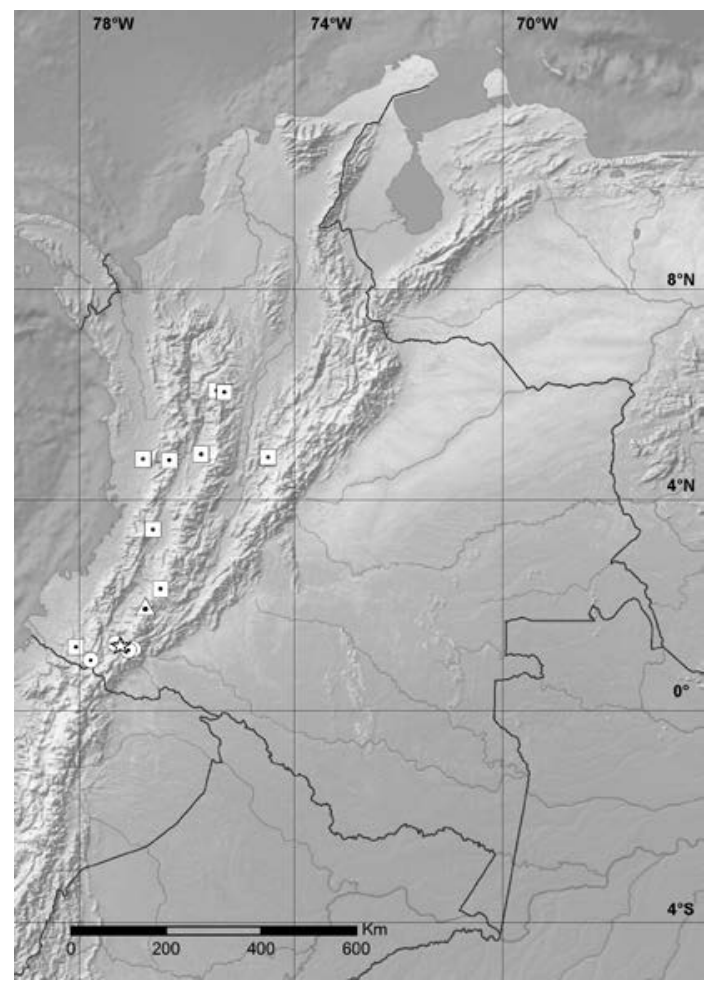

Fig. 2. Distribution of Pleurothallis narinoensis Rykaczewski \& Kolan., sp. nov. (is), P. taurus Luer $(\triangle)$, P. ramificans Luer $(\bigcirc)$, and P. antennifera $(\square)$ in Colombia.

ramicaul, glabrous. Leaf 30-60 mm long, 11-16 mm wide, linear-elliptic, apex apiculate, acute, margins entire. Floral bracts $4-5 \mathrm{~mm}$ long, tubular, acuminate, glabrous. Raceme up to $20 \mathrm{~cm}$ long, longer than leaf, loose, simultanously few-flowered. Spathe $12-15 \mathrm{~mm}$ long. Ovary $3.5 \mathrm{~mm}$ long. Pedicel 3-4 mm long. Dorsal sepal $8 \mathrm{~mm}$ long, $2.7 \mathrm{~mm}$ wide, lanceolate-ovate, obtuse, concave, margins entire, 3-veined. Lateral sepals $7 \mathrm{~mm}$ long, $4 \mathrm{~mm}$ wide, connate with triangular, acute, 4-veined synsepal. Petals $7.5 \mathrm{~mm}$ long, $0.8 \mathrm{~mm}$ wide, linear, acute at apex, margins glabrous, 1-veined. Lip 3-lobed, $3 \mathrm{~mm}$ long, $7.5 \mathrm{~mm}$ across lateral lobes, 3-veined; lateral lobes $3 \mathrm{~mm}$ long, $1.1 \mathrm{~mm}$ wide, linear-lanceolate, acute; middle lobe $1.5 \mathrm{~mm}$ long, semicircular with linear-oblong, acute apicule 0.5 long, $0.2 \mathrm{~mm}$ wide, margin irregular, base covered by transverse foveolate ridge. Gynostemium $1.5 \mathrm{~mm}$ long, slightly widened at base, stout, terete. 
A
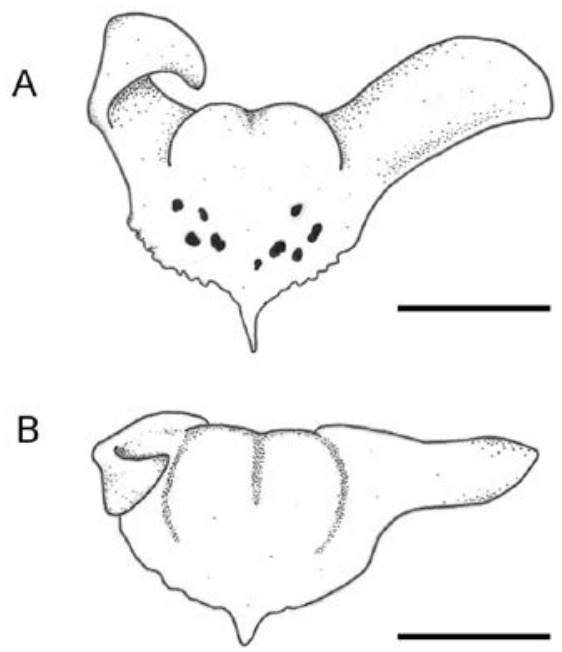

C

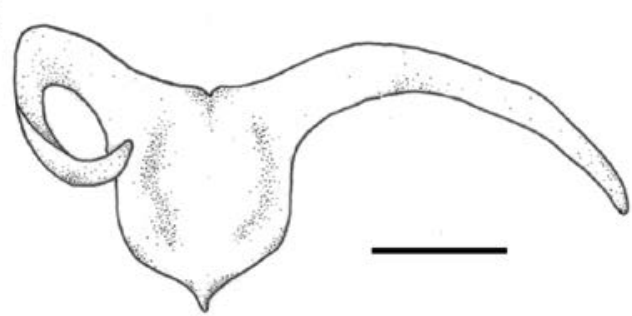

Fig. 3. Lip form of Pleurothallis antennifera Lindl. (A), P. ramificans Luer (B) and P. taurus Luer (C). Scale bars $=1 \mathrm{~mm}$. Redrawn by M. Rykaczewski from Luer 1999, figs 2, 26, 33 (permission granted by Missouri Botanical Garden Press, St. Louis).

Habitat, ecology and distribution. Pleurothallis narinoensis was found in wet paramo vegetation among scrub at 2700-3000 m a.s.l. Flowering occurs in August. So far this species is known exclusively from a single collection made in the southern Colombian Andes (Fig. 2).

TAXONOMIC NOTES. The proliferating ramicauls observed in the new species occur commonly in Pleurothallis taurus and P. ramificans, rarely in $P$. antennifera. Linear-elliptic leaves are observed in $P$. ramificans and $P$. narinoensis. Both P. taurus and $P$. antennifera produce elliptic-ovate leaves. In both $P$. ramificans and $P$. antennifera the lip lateral lobes are oblong; their length is subequal to the middle lobe width. Long lip lateral lobes are observed in P. taurus but in this species the middle lobe of the lip is shortly acuminate, with an entire margin.
Irregular margins of the middle lobe are found in $P$. antennifera and $P$. ramificans. The lip forms of the three discussed species are presented in Fig. 3.

\section{Key to the Colombian SPECiES OF PleURothalLIS SUBG. PleURothalLIS SECT. PleURothaLLIS SUBSECT. ANTENNIFERAE (Luer 1999, modified)}

1. Leaf narrowed into subpetiolate base $\ldots \ldots \ldots 2$ 1 . Leaf sessile . . . . . . . . . . . . . . . . . 3

2. Lip middle lobe obtuse to rounded $\ldots \ldots \ldots \ldots$ ........... P. pulvinaris Luer \& R. Escobar 2. Lip middle lobe oblong, acute . . P. tuzae Luer 3. Leaf base cordate ................ 4 3. Leaf base cuneate . . . . . . . . . . . . . . . . . . 5

4. Sheaths of ramicaul inflated $\ldots \ldots \ldots \ldots \ldots$ .......... P. manicosa Luer \& R. Escobar 4. Sheaths of ramicaul not inflated .......... $\ldots \ldots \ldots \ldots$ P. penduliflora Kraenzl.

5. Lip lateral lobes narrow $\ldots \ldots \ldots \ldots \ldots \ldots 6$ 5. Lip lateral lobes broad . . . . . . . . . . 8

6. Lip lateral lobes longer than middle lobe ... 7 6. Lip lateral lobes subequal in length to middle lobe $\ldots \ldots \ldots \ldots \ldots \ldots$ P. ramificans Luer

7. Lip middle lobe shortly acuminate, with entire margin ................. taurus Luer

7* Lip middle lobe with acute appendix, margin irregular ... P. narinoensis Rykaczewski \& Kolan. 8. Lip with lobe-like lateral margins ....... 9 8. Lip with well-demarcated lateral lobes .... 11

9. Lip with basal lobes ... P. imbaburae Luer \& Hirtz 9. Lip without basal lobes . . . . . . . . . . . 10

10. Lip not acutely revolute .............. ............... P. cymbisepala Schltr. 10*. Lip acutely revolute . . . . . . . . . . . . . . ........ P. revoluta (Ruiz \& Pav.) Garay

11. Lip lateral lobes elongate, narrow ....... 12

$11^{*}$ Lip lateral lobes antrorse, broad . . . . . . . 14

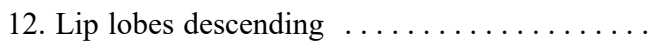

P. trifurcata Luer \& Hirtz

12*. Lip lobes antrorse, incurved . . . . . . 13

13. Lip lateral lobes subequal in length to middle lobe

$\ldots \ldots \ldots \ldots \ldots \ldots$. brachiata Luer

13. Lip lateral lobes longer than middle lobe ......

$\ldots \ldots \ldots$ P. hippocrepica Luer \& R. Escobar

14. Lip middle lobe reflexed $180^{\circ} \ldots \ldots \ldots \ldots$

P. bicochlearis Luer

$14^{*}$ Lip middle lobe reflexed $90^{\circ} \ldots \ldots \ldots 15$ 
15. Lip middle lobe round, minutely apiculate ...... $\ldots \ldots \ldots \ldots \ldots \ldots$ P. antennifera Lindl. 15*. Lip middle lobe long-apiculate . . . . . . . 16

16. Synsepal deeply concave, lip lateral lobes narrowed at base ....... P. genychila Schltr.

16. Synsepal deeply concave, lip lateral lobes not narrowed at base .......P. nasiterna Luer

AcKnowledgements. We are grateful to Natalia Olędrzyńska for preparing the illustrations of the new species and to Missouri Botanical Garden Press for permission to reproduce illustrations published in Icones Pleurothallidinarum XVIII. We thank Professor Dariusz Szlachetko and the anonymous reviewers for valuable comments on the manuscript. The research described here was supported by the Foundation for Polish Science.

\section{REFERENCES}

Borba E. L., Felix J. M., Semir J. \& Solferini V. N. 2000. Pleurothallis fabiobarrosii, a new Brazilian species: morphological and genetic data, and notes on the taxonomy of Brazilian rupicolous Pleurothallis. Lindleyana 15: 2-9.
Luer C. A. 1986. Icones Pleurothallidinarum I. Systematics of the Pleurothallidinae. Monogr. Syst. Bot. Missouri Bot. Gard. 15: 1-81.

LuER C. A. 1998. Icones Pleurothallidinarum XVII. Systematics of Pleurothallis sections Abortivae, Truncatae and Pleurothallis subsections Acroniae and Amphygiae (Orchidaceae). Monogr. Syst. Bot. Missouri Bot. Gard. 72: $1-121$.

Luer C. A. 1999. Icones Pleurothallidinarum XVIII. Systematics of Pleurothallis, subgen. Pleurothallis sect. Pleurothallis, subsect. Antenniferae, subsect. Longiracemosae, subsect. Macrophyllae-Racemosae, subsect. Perplexae; subgen. Pseudostelis; subgen. Acuminatia. Monogr. Syst. Bot. Missouri Bot. Gard. 76: 1-182.

LUER C. A. 2002. A systematic method of classification of the Pleurothallidinae versus a strictly phylogenetic method. Selbyana 23(1): 57-110.

Pridgeon A. M. \& Chase M. W. 2001. A phylogenetic reclassification of Pleurothallidinae (Orchidaceae). Lindleyana 16: $235-271$.

Pridgeon A. M., Solano R. \& Chase M. W. 2001. Phylogenetic relationships in Pleurothallidinae (Orchidaceae): combined evidence from nuclear and plastid DNA sequences. Amer. J. Bot. 88: 2286-2308. 